\title{
Determining the Independence and Professional Skills on Audit Quality at the General Election Supervisory Agency (Bawaslu) of Indonesia
}

\author{
Asmin Safari Lubis ${ }^{1 *}$, Hadri Mulya ${ }^{2}$ \\ ${ }^{1}$ Master of Accounting, Universitas Mercu Buana, Jakarta, Indonesia \\ 2 Lecturer at Universitas Mercu Buana, Jakarta, Indonesia
}

ART ICLE INF O

\section{Article history}

Received July 10, 2021

Revised July 13, 2021

Accepted August 01, 2021

Available online August 25, 2021

\section{Keywords}

Effect of Auditor Competence,

Auditor Independence,

Professional Skills, Audit

Quality, General Election

Supervisory Body of the

Republic of Indonesia (Bawaslu $\mathrm{RI})$

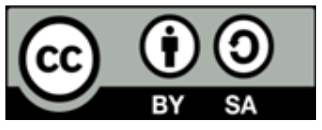

This is an open access article under the CC BY-SA license.

Copyright (C) 2021 by Author. Published by Universitas Pendidikan Ganesha.

\begin{abstract}
A B S T R A C T
A common way to obtain reliable information is to require an independent audit to be conducted so that the information used in decision making is complete, accurate, and unbiased. This study aims to determine the effect of Auditor Competence, Auditor Independence and Professional Skills on Audit Quality at the General Election Supervisory Agency of the Republic of Indonesia (Bawaslu RI) and Provinces throughout Indonesia. The research model describes a conceptual framework as a guide as well as a flow of thought in developing hypotheses. The model in this study describes the influence of personal auditor factors consisting of competence, independence, professional skills on audit quality. The data collection technique in this study used multiple regression analysis using the EViews program. Data analysis techniques include descriptive statistical tests, research instrument tests, classical assumption tests, model determination tests, and hypothesis testing. The results of the study indicate that competence has a positive effect on audit quality at the RI Bawaslu. These results can be used as consideration by the RI Bawaslu to be able to further improve the quality of audits on auditors, because the higher the competence of the auditors, the higher the audit quality. Independence does not have a positive effect on audit quality at the RI Bawaslu. Professional skills have a positive effect on audit quality at the RI Bawaslu. Professional skills are important things that must be applied by every public accountant in carrying out their professional work in order to achieve adequate audit quality.
\end{abstract}

\section{INTRODUCTION}

Users of financial statements will always check and seek information about the reliability of the company's financial statements. A common way to obtain reliable information is to require an independent audit to be conducted so that the information used in decision making is complete, accurate, and unbiased. Without using the services of an independent auditor, the company's management will not be able to convince outsiders that the financial statements presented by the company's management contain reliable information. Because from the perspective of outsiders, management also has interests, both financial and other interests. Usually, management will request that the auditor provide assurance to users that the financial statements can be relied upon (Ardini, 2010; Bawono \& Singgih, 2010). Previous study provides empirical evidence that due professional care is the most influential factor on audit quality (Achmad, 2012; Harris \& Duellman, 2021). Another study concluded that audit failure in related party transaction fraud cases was caused by a lack of skepticism and due professional care auditors (Achmad, 2012; Kumalasari et al., 2020). Careful and thorough professional skills of auditors show professional judgment (professional judgment) carried out by the auditor during the examination (Achmad, 2012). From the number of studies on audit quality, it can be concluded that the importance of the audit quality of an auditor in producing reliable financial statements. Several factors that can affect audit quality include: competence, independence, accountability, and due professional skills. This is supported by research which states that competence and independence are indicators that can affect audit quality (Christiawan, 2002). In addition, the success and performance of someone who does a field of work will be determined from the level of competence possessed (Ardini, 2010). 
Audit quality is the probability that an auditor can find and report violations in the client's accounting system (DeAngelo, 1981; Sirois \& Simunic, 2011). The probability of finding a violation will depend on the technical ability of the auditor, and the probability of reporting a violation will depend on the independence of the auditor (Deis Jr \& Giroux, 1992). From these two definitions, the auditor will be declared competent if the auditor is able to find a violation, and an independent auditor is an auditor who is willing to disclose the discovery of the violation (Bawono \& Singgih, 2010). In addition, auditor competence is a fundamental thing for an auditor in order to produce quality audit reports and be supported by adequate knowledge, skills, experience, and education (Alim et al., 2007). The results of the research also state that competence is something that affects audit quality (Perdany, 2014). The higher the competence of the auditor, the better the audit quality (Achmad, 2012) (Puspitasari et al., 2019). In addition to having good competence, auditors are required to have an independent attitude, namely a mental attitude that is not easily influenced, controlled, and depending on others. Independence is an impartial attitude, and is one of the factors that determine the credibility of the auditor's opinion (Adebayo, 2021; Harris \& Duellman, 2021; Manayseh \& Stalin, 2020). Auditors who do not appear independent will make users of financial statements increasingly distrustful of the resulting financial statements, and the audit opinion on the financial statements will become worthless. An auditor must have an honest attitude to internal and external parties who put their trust in the audited financial statements (Wiratama \& Budiartha, 2015). Independence can be interpreted as a mental attitude that is not influenced and controlled by other parties, and does not depend on others (Mulyadi, 2002).

Another factor that affects audit quality is professional proficiency. The third general standard in the auditor profession is professional skill which means being professional and having the responsibility to carry out their duties diligently and thoroughly (Arens et al., 2008). This statement is reinforced by research that stated auditors who have professional skills are required to have professional skepticism, namely a critical thinking attitude towards audit evidence, and always question and evaluate audit evidence carefully (Zimmerman, 2008). This is supported by research which states that professional skills are things that must be applied by public accountants so that adequate audit quality is achieved in carrying out their work professionally (Febriyanti, 2014). Some of the results of these studies prove that the professional skills applied in the work of auditors will result in better audit quality. According to Statements of Financial Accounting Concepts (SFAC, 2000) audit quality results will be determined by several factors, including competence and independence. The competence and independence of an auditor is closely related to the process and results of good audit quality. Without these factors, audit quality is still questionable, difficult to trust, accountable, and cannot be used to make decisions. Auditor competence will be influenced by formal education and technical training followed by auditors (Christiawan, 2002). Likewise, independence is one of the important factors for auditors in carrying out their profession so that they are not easily influenced by the internal and external environment (Perdany, 2014). In addition to competence and independence, professional skills are also needed, in which the auditor has a careful and thorough attitude by thinking critically and evaluating audit evidence, is not careless in conducting examinations, is careful in carrying out his duties, and is firm in carrying out his duty's responsibility (Angel RG \& Parlindungan, 2016).

An auditor in order to be able to find and report any findings of violations in the financial statements made by the principal is largely determined by the quality of the audit (Nirmala \& Cahyonowati, 2013). One of the things that must be possessed by an auditor who has good audit quality is competence because with competence, the auditor will be supported by the knowledge, skills, experience, and education he gets (Efendy, 2010). The auditor's professional skills in carrying out their duties will determine their quality by having an attitude of prudence when conducting audits. Professional skills can be interpreted as a careful attitude, thorough, critical thinking, and will evaluate the audit evidence found. Several previous studies have proven that the important things that must be possessed by auditors to carry out their duties as public accountants are competence, independence, and professional skills. Independence and professional skills have a positive influence on audit quality (Wiratama \& Budiartha, 2015). This is supported by the research which states that the higher the independence and professional proficiency of the auditor, the higher the audit quality (Febriyanti, 2014). Competence and independence have a positive influence on audit quality (Alim et al., 2007). These results are reinforced by research which states that competence, independence, and accountability have an influence on audit quality (Ardini, 2010).

Indonesia is one of the countries that has a high level of violations of the use of funds in the world. According to statistical data from ICW (Indonesian Corruption Watch), almost all state institutions from the village level to State-Owned Enterprises (BUMN) are involved in corruption of people's money, which in total could be in the tens of trillions (Nurhasanah, 2020). With these conditions, the quality of audits in an institution or organization that uses public money from taxes for its implementation is very necessary. The poor quality of financial audits in a state institution will cause the current acts of corruption to be more widespread and uncontrolled. From here we consider it important to conduct this research, where the audit 
quality of state institutions such as Bawaslu which has been declared WTP for five consecutive years by the $\mathrm{BPK}$, can be an example for other institutions in the context of fighting and reducing corruption that is increasingly widespread in Indonesia. Facts on the ground show that even though Bawaslu has received the WTP title from the BPK, there are still individuals who are corrupt and abuse their authority within this institution. This is where the important role of a financial auditor in an institution or organization is. Auditor Competence, Auditor Independence and Professional Skills on Audit Quality must be evenly distributed from the central to regional levels, even to the village level throughout Indonesia. Therefore, this study aims to determine the effect of auditor competence, auditor independence and professional skills on audit quality at the agency for the general elections supervisory agency of the republic of Indonesia (Bawaslu RI) and all provinces throughout Indonesia.

\section{METHODS}

The research model describes a conceptual framework as a guide as well as a flow of thought in developing hypotheses. The model in this study describes the influence of personal auditor factors consisting of competence, independence, professional skills on audit quality. The population in this study were all internal auditors who worked at the RI Bawaslu and the Indonesian Bawaslu. The right sampling method to use is the non-probability method (Sekaran, 2011). The criteria used in determining the sample are: (1) The government's internal auditor who works for the RI Bawaslu based at the head office in Jakarta (not a regional representative office); (2) Government internal auditor who has status as a Civil Servant; (3) Government internal auditors who have attended the Certification Training for the Establishment of Government Internal Auditors (for expert and skilled level team members); (4) Government internal auditors who have experience in auditing for at least 1 (one) year; (5)The government's internal auditor is willing to respond to the questionnaire given.

The data used in this study are secondary data and primary data. Data collection techniques, especially primary data in this study were carried out by survey methods through questionnaires. The latent variables in this study are audit quality, ethical understanding, auditor competence, auditor independence, auditor accountability, audit experience, and gender. Meanwhile, the observed variables which are the effects or measures of the latent variables are the question items used to measure the constructs of the related latent variables. The data collection technique in this study used multiple regression analysis using the EViews program. Data analysis techniques include Descriptive Statistical Test, Research Instrument Test, Classical Assumption Test, Model Constancy Test, and Hypothesis testing. The individual parameter significant test ( $t$ statistical test) is intended to see whether the individual variables have an influence on the dependent variable with the assumption that the other independent variables are constant.

\section{RESULTS AND DISCUSSIONS}

\section{Results}

\section{Respondents Overview}

The demographic characteristics of respondents in this study are profiles of 90 respondents from auditors who were respondents in filling out this questionnaire. The demographic characteristics of these respondents include gender, age, last education, position, work experience, and education or training regarding audits that they have attended. The demographics of the respondents in this study can be seen in Table 1.

Table 1. Description of Respondent Characteristics

\begin{tabular}{cccc}
\hline Indicators/Aspects & Sub-Indicators & Amount & Percentage \\
\hline \multirow{2}{*}{ Age } & $20-25$ years & 28 & $31.1 \%$ \\
& $26-30$ years & 2 & $2.2 \%$ \\
\multirow{2}{*}{ Gender } & $31-35$ years old & 16 & $17.8 \%$ \\
& $>35$ years old & 44 & $48.9 \%$ \\
& Man & 57 & $63.3 \%$ \\
Year of Service & Woman & 33 & $36.7 \%$ \\
& 15 years & 80 & $88.9 \%$ \\
& $6-10$ years & 5 & $5.6 \%$ \\
\hline
\end{tabular}




\begin{tabular}{cccc}
\hline Indicators/Aspects & Sub-Indicators & Amount & Percentage \\
\hline & D & 29 & $32.2 \%$ \\
Latest Education & S1 & 44 & $48.9 \%$ \\
& S2 & 17 & $18.9 \%$ \\
Training on Audits that Have Been & S3 & 0 & $0 \%$ \\
Attended & $1-3$ times & 27 & $30 \%$ \\
& $4-6$ times & 54 & $60 \%$ \\
& $7-9$ times & 6 & $6.7 \%$ \\
& $>10$ times & 3 & $3.3 \%$ \\
\hline
\end{tabular}

\section{Validity Test}

The validity test in this study used the EViews test tool with the aim of regulating the validity of each question asked submitted to the respondent. In this validity test, the technique used is a correlation technique, which is a technique that compares the results of the coefficient with the correlation of $r$-count with r-table. Validity test results is presented in Table 2.

Table 2. Validity Test Results

\begin{tabular}{|c|c|c|c|c|c|c|c|c|}
\hline \multicolumn{5}{|c|}{ Competency Variable (X1) } & \multicolumn{4}{|c|}{ Independent Variable (X2) } \\
\hline No & Items & $\mathbf{r}_{\text {count }}$ & $\mathbf{r}_{\text {table }}$ & Information & Items & $\mathbf{r}_{\text {count }}$ & $\mathbf{r}_{\text {table }}$ & Information \\
\hline 1 & Item 1 & 0.499 & 0.213 & Valid & Item 1 & 0.263 & 0.213 & Valid \\
\hline 2 & Item 2 & 0.321 & 0.213 & Valid & Item 2 & 0.527 & 0.213 & Valid \\
\hline 3 & Item 3 & 0.484 & 0.213 & Valid & Item 3 & 0.436 & 0.213 & Valid \\
\hline 4 & Item 4 & 0.447 & 0.213 & Valid & Item 4 & 0.088 & 0.213 & Invalid \\
\hline 5 & Item 5 & 0.674 & 0.213 & Valid & Item 5 & 0.412 & 0.213 & Valid \\
\hline 6 & Item 6 & 0.626 & 0.213 & Valid & Item 6 & 0.375 & 0.213 & Valid \\
\hline 7 & Item 7 & 0.556 & 0.213 & Valid & Item 7 & 0.472 & 0.213 & Valid \\
\hline 8 & Item 8 & 0.418 & 0.213 & Valid & Item 8 & 0.422 & 0.213 & Valid \\
\hline 9 & Item 9 & 0.780 & 0.213 & Valid & Item 9 & 0.582 & 0.213 & Valid \\
\hline 10 & Item 10 & 0.532 & 0.213 & Valid & Item 10 & 0.136 & 0.213 & Invalid \\
\hline \multicolumn{5}{|c|}{ Professional Proficiency Variable (X3) } & \multicolumn{4}{|c|}{ Audit Quality Variable (Y) } \\
\hline 1 & Item 1 & 0.511 & 0.213 & Valid & Item 1 & 0.586 & 0.213 & Valid \\
\hline 2 & Item 2 & 0.616 & 0.213 & Valid & Item 2 & 0.744 & 0.213 & Valid \\
\hline 3 & Item 3 & 0.742 & 0.213 & Valid & Item 3 & 0.630 & 0.213 & Valid \\
\hline 4 & Item 4 & 0.685 & 0.213 & Valid & Item 4 & 0.818 & 0.213 & Valid \\
\hline 5 & Item 5 & 0.636 & 0.213 & Valid & Item 5 & 0.554 & 0.213 & Valid \\
\hline 6 & Item 6 & 0.769 & 0.213 & Valid & & & & \\
\hline 7 & Item 7 & 0.0653 & 0.213 & Valid & & & & \\
\hline 8 & Item 8 & 0.556 & 0.213 & Valid & & & & \\
\hline 9 & Item 9 & 0.820 & 0.213 & Valid & & & & \\
\hline 10 & Item 10 & 0.675 & 0.213 & Valid & & & & \\
\hline 11 & Item 11 & 0.732 & 0.213 & Valid & & & & \\
\hline 12 & Item 12 & 0.728 & 0.213 & Valid & & & & \\
\hline 13 & Item 13 & 0.853 & 0.213 & Valid & & & & \\
\hline 13 & Item 13 & 0.853 & 0.213 & Valid & & & & \\
\hline
\end{tabular}

The results of the calculation of the correlation coefficient mostly have $r$-count greater than $r$-table ( $\mathrm{r}$-table $=0.213$ ), and there are 3 items that have r-count value smaller than r-table, namely item 2 on the competency variable, item 1 and 10 on the independence variable. For items that are not valid, revisions are made both in terms of language and material by adjusting the indicators in the study using expert tests. So it was concluded that all the questions on the instrument from the questions of competence (X1), independence (X2), professional skills (X3), and audit quality $(\mathrm{Y})$ were valid and worthy of being an instrument for measuring research on the effect of audit quality. 


\section{Reliability Test}

The reliability test aims to see the consistency of the answers. This test on the EViews system uses the Cronbach's Alpha statistical test, and is said to be reliable if the Cronbach's Alpha value is $>0.5$. The reliability test results is presented in Table 3.

Table 3. Reliability Test Results

\begin{tabular}{lccc}
\hline \multicolumn{1}{c}{ Variable } & Cronbach's Alpha & Critical Value & Information \\
\hline Competence & 0.337 & 0.5 & Reliable \\
Independence & 0.229 & 0.5 & Reliable \\
Professional Skills & 0.381 & 0.5 & Reliable \\
Audit Quality & 0.284 & 0.5 & Reliable \\
\hline
\end{tabular}

Based on the results of the reliability test, it can be concluded that all questions used to measure the independent variables are reliable because Cronbach's Alpha $>0.5$.

\section{Normality Test}

The normality test has a purpose to test whether in the regression model the variables are normally distributed. Based on the data analysis results, it is stated that the Significance value obtained through the one-sample Kolmogorov-Smirnov (KS) test of 0.242 indicates that it is greater than $(0.05)$, it can be concluded that the data has a normal distribution.

\section{Multicollinearity Test}

The multicollinearity test was used to determine whether the regression model in the study found a correlation in the independent variables or not. If the VIF value is $<10$ and the tolerance value is $>0.1$, it means that there is no correlation between the independent variables, and vice versa. The multicollinearity test results is presented in Table 4

Table 4. Multicollinearity Test Results

\begin{tabular}{lccc}
\hline \multicolumn{1}{c}{ Independent Variable } & tolerance & VIF & Conclusion \\
\hline Competence & 0.005 & 1,135 & There is no multicollinearity \\
Independence & 0.005 & 1,169 & There is no multicollinearity \\
Professional Skills & 0.001 & 1.066 & There is no multicollinearity \\
\hline
\end{tabular}

\section{Heteroscedasticity Test}

This heteroscedasticity test aims to find out whether there are similar variants of each independent variable $\mathrm{X} 1, \mathrm{X} 2$, and $\mathrm{X} 3$ to the dependent variable $(\mathrm{Y})$. The heteroscedasticity test results is presented in Table 5 .

Table 5. Heteroscedasticity Test Results

\begin{tabular}{cccc}
\hline F-statistics & 3,326 & Prob. F(9,80) & 0.0617 \\
\hline R-squared & 24,506 & Prob. Chi-Square (9) & 0.0636 \\
\hline Scaled Explained SS & 12.77 & Prob. Chi-Square (9) & 0.1733 \\
\hline
\end{tabular}

The results of the Heteroscedasticity test white are indicated by the value of Prob chi square (2) on $\mathrm{R}$-Squared is 0.0617 . Because the $\mathrm{p}$ value is $0.0617>0.05$, the regression model is homoscedastic or in other words, it can be concluded that there is no heteroscedasticity.

\section{Coefficient of Determination Test}

The amount of adjusted R2 (coefficient of determination that has been adjusted) is 0.3194 . This value indicates that the influence of three independent variables, namely competence, independence, and professional skills is $31.9 \%$ or $32 \%$ and the remaining $68 \%$ is influenced by other factors outside the research model. Based on the results of analysis data shows that, the value of F-count $14.924>$ F-table is 2.71 the significance value is $0.000<0,05$. So it can be concluded that the variables of competence, auditor independence, professional skills on audit quality can be said to be feasible for research. 


\section{Hypothesis Test (t-test)}

The $t$ test is a test used to determine the level of influence between each independent variable partially on the dependent variable. The t-test can be determined by comparing the $t$-count value with the $\mathrm{t}$-table value with $\mathrm{df}=(90-2)=88$ there is a table of 0.05 significance which is 1.987 . If the value of $\mathrm{t}$-count is greater than t-table of 1,987 or a significance value of less than 0.05 , so that the independent variable $(\mathrm{X})$ partially has a significant effect on the independent variable (Y). From the results of the $T$ test analysis, it shows that: First, the Competency Variable (X1) statistically shows a significance result of 0.002 which is smaller than 0.05 . While the value of $\mathrm{t}$-count $\mathrm{X} 1=3.183$ and $\mathrm{t}$-table of 1.987 , so that $\mathrm{t}$-count $>\mathrm{t}$-table $(3.183$ $>1.987$ ). Thus, the first hypothesis is accepted so that it can be concluded that the competence variable has a positive influence on audit quality. Second, the Independent Variable (X2) statistically shows a significance result of 0.649 which is greater than 0.05 . While the value of $t$-count $X 2=0.649$ and $t$-table of 1.987 , so that $\mathrm{t}$-count $>\mathrm{t}$-table $(0.649<1.987)$. Thus, the second hypothesis is rejected so that it can be concluded that the independence variable does not have a positive effect on audit quality. Third, the Professional Proficiency variable (X3) statistically shows a significance result of 0.000 which is smaller than 0.05 . While the value of $\mathrm{t}$-count $\mathrm{X} 3=5.550$ and $\mathrm{t}$-table of 1.987 , so $\mathrm{t}$-count $>\mathrm{t}$-table $(5.550>1.987)$. Thus the third hypothesis is accepted so that it can be concluded that the professional proficiency variable has a positive influence on audit quality.

\section{Discussion \\ The Effect of Competence on Audit Quality}

The first hypothesis states that competence has a positive effect on audit quality. The results of the $\mathrm{t}$ test indicate that the significance value is $0.002<0.05$. This shows that $\mathrm{H} 1$ is accepted, so it can be concluded that the competency variable partially affects the audit quality at the RI Bawaslu office. The first hypothesis (H1) which states "competence has a positive effect on audit quality" is proven. These results agree with the opinion which states that the probability that the auditor will find misstatements will depend on the quality of understanding (competence) of the auditor himself (DeAngelo, 1981). Audit quality is the possibility of the auditor in auditing the client's financial statements to find a violation that occurred in the accounting system and report the violation into the audited financial report, where the auditor in carrying out his duties is guided by auditing standards and the code of ethics of public accountants (Tjun et al., 2012).

In order for the auditor to fulfill good audit quality to be able to carry out his duties as an examiner, an auditor must be guided by the code of ethics of accountants, professional standards, and accounting standards that apply in Indonesia. This has the aim that the auditors maintain their integrity and objectivity in carrying out their duties. Therefore, auditing standards state that audits are carried out by people who have expertise, independent attitudes, and professional skills that are used carefully and thoroughly (Layli, 2018). In the research stated that in the public sector Government Accountability Office (GAO), audit quality is defined as adherence to professional standards and contractual ties during the audit (Lowenshon et al., 2005). Audit quality will have an impact on every decision making in the implementation of the audit, so it is hoped that every decision taken is the right decision (Perdany, 2014). Another study explains that in order to improve audit quality, auditors will depend on their level of competence. The better the competence of the auditor, the easier it will be to carry out the audit task, and the lower the audit competence, the more difficult it will be for the auditor to carry out his audit task so that the audit quality will decrease (Efendy, 2010).

Employing people with high experience increases audit quality by enhancing the professional competence of the auditor; auditors gain a deeper knowledge and better judgement to achieve audit quality (Zahmatkesh \& Rezazadeh, 2017). Thus, the accountability improves auditor's performance and objectivity of auditors enables them to operate without the influence of another individual. The results in this study are in line with research which state that competence has an influence on audit quality (Akib \& La, 2021; Alim et al., 2007; Ardini, 2010; Iryani, 2017; Kartika \& Pramuka, 2019; Meidawati \& Assidiqi, 2019; Mispiyanti \& Wicaksono, 2021; Muslim et al., 2020; Sari \& Susanto, 2018; Tjun et al., 2012). However, it is different from the results which states that Auditor's competence has no effect on audit quality whether it directly or indirectly (Kumalasari et al., 2020; Kusumawati \& Syamsuddin, 2018).

\section{Influence of Independence on Audit Quality}

The second hypothesis states that independence has a positive effect on audit quality. The t test results show that the significance value is $0.649>0.05$. This shows that $\mathrm{H} 2$ is rejected, so it can be concluded that the independence variable partially does not affect the audit quality at the RI Bawaslu office. Thus, the second hypothesis (H2) which states "independence has a positive effect on audit quality" is not proven. This is because when measuring auditor independence, it is not derived from the mental attitude of the auditor. Researchers who are interested in conducting research on audit quality should consider using 
quality measures derived from the mental attitude of the auditors (Widiastuty \& Febrianto, 2010). The importance of independence for an auditor are: (1) Independence is an important requirement for auditors in carrying out their audit duties with the aim of assessing financial statements, (2) Auditors are trusted by users of financial statements as parties who independent in order to provide assurance regarding management's assertions, (3) Independence is a factor that greatly affects audit quality (Bawono \& Singgih, 2010). This is supported by previous study that the auditor is required to be independent (not easily influenced) because he is carrying out work in the public interest, so the auditor is not justified in taking sides (Saripudin et al., 2012).

Independence is not only an emphasis on the important value of independence in auditing, but must also be placed on the appearance and reality side (in appearance and in fact) (Mautz \& Sharaf, 1961). According to him, there are two aspects of independence, namely (a) the real independence of a practitioner in carrying out their duties, and (2) independence in the appearance of an auditor as a professional group. This is called "practitioner independence" and "professional independence". Practitioner independence is related to the ability of an individual practitioner to maintain appropriate or appropriate behavior in the design of his or her audit program. While the independence of the profession has a relationship with the image of the auditor as a group. The independence of this profession relates to how the public perceives auditors: whether auditors are simply a group of completely independent professionals or simply a group of hired people such as bookkeepers. If one day they have to rely on the work of an auditor, the first impression they will have is the impression that will govern their actions (Mautz \& Sharaf, 1961).

Regulatory utilitarianism means that a person must act in accordance with applicable rules in order to produce the common good. In this case, the level of independence of election supervisory members is included in the high category where from each category in the questionnaire starting from being honest in taking action, being honest in reporting, integrity of election supervisors, professionalism of election supervisors and finally carrying out their duties and authorities in accordance with applicable rules, showing that the members of the election supervisory board supervise the implementation of the election from the whole process of stages properly. So that in terms of function, election supervisors have carried out their functions properly and in accordance with applicable regulations. However, not all Panwaslu members have a high level of independence.

It is undeniable that the performance of each member of the election supervisory board is different so that the independence of each person is also different, this is from the results of the independence research of election supervisors that not everyone has a high level of independence but there are also those who have a moderate level of independence and not There are election supervisory members who have low independence, this can mean that election supervisory members have very high independence because the independence of members of the election management body is very much needed and election supervisory members who have a low level of independence, this must be improved again in the implementation of their duties and obligations in the implementation of election supervision in the implementation of the next election. The use of independent variables in research should be proxies by four sub-variables, namely (a) length of relationship with clients, (b) pressure from clients, (c) peer-auditor reviews, and (d) non-audit services. The results are in line with the study which states that there is no relationship between independence and audit quality, this is because when the measurement of auditor independence is not derived from the mental attitude of the auditor (Samelson et al., 2006). Another study that supports these results is the research which states that research on audit quality will be better if you consider the use of quality measures derived from the mental attitude of the auditor (Widiastuty \& Febrianto, 2010). Another studies that are in line with the result of this study are: the research which state that independence has no effect on audit quality (Angel RG \& Parlindungan, 2016; Efendy, 2010; Febriyanti, 2014; Kumalasari et al., 2020; Meidawati \& Assidiqi, 2019; Tjun et al., 2012). However, this study is not in line with research which state that independence has an effect on audit quality (Achmad, 2012; Alim et al., 2007; Haeridistia \& Agustin, 2019; Kartika \& Pramuka, 2019; Lamba et al., 2020; Mardijuwono \& Subianto, 2018; Marwa et al., 2019; Mispiyanti \& Wicaksono, 2021; Pritama et al., 2018; Puspitasari et al., 2019; Wiratama \& Budiartha, 2015; Yazid \& Wiyantoro, 2018).

\section{Effect of Professional Proficiency on Audit Quality}

The third hypothesis states that professional proficiency has a positive effect on audit quality. The $\mathrm{t}$-test results show that the significance value is $0.000<0.05$. This shows that $\mathrm{H} 3$ is accepted, so it can be concluded that the competence variable partially affects the audit quality at the RI Bawaslu office. Thus, the third hypothesis (H3) which states "professional proficiency has a positive effect on audit quality" is proven. These results mean that increasing professional skills has an effect on audit quality. It is important for auditors to implement professional skills in their audit work. Auditors are required to always think critically about audit evidence by always questioning and evaluating the evidence. The careful and thorough use of 
professional skills enables the auditor to obtain reasonable assurance about whether the financial statements are free from material misstatement, whether caused by error or fraud. Professional skills are important things that must be applied by every accountant in carrying out their professional work in order to achieve adequate audit quality. Professional skills involve two aspects, namely professional skepticism and adequate belief. Public trusts the financial statements if the auditor has used his professional skepticism in the audit implementation process (Syukroni, 2018).

Indicators of skepticism and belief have less influence on the audit results produced by the auditor (Saripudin et al., 2012). Professional skills have no effect on audit quality because there is a possibility of an impact on the auditor from several financial scandal events that have occurred (Bawono \& Singgih, 2010). The impact is the growing awareness to be more careful in carrying out their duties as an auditor. However, with the financial scandal that occurred, auditors feel increasingly constrained by new, stricter regulations, and auditors feel that their profession is increasingly threatened by severe consequences such as loss of public trust in the auditor profession, as well as existing legal sanctions. Due diligence requires the auditor to be aware of significant risks. With a careful attitude, the auditor will be able to uncover various kinds of fraud in the presentation of financial statements more easily and quickly. For this reason, in evaluating audit evidence, auditors are required to have adequate confidence (Wiratama \& Budiartha, 2015). Auditors must also maintain professional skepticism during the examination process, because when the auditor is no longer able to maintain professional skepticism, the audited financial statements cannot be trusted anymore, and allow litigation on the audit (Bawono \& Singgih, 2010). This study is in line with the research where the results of his research found evidence that professional skills have a positive influence on audit quality (Arowoshegbe et al., 2017; Febriyanti, 2014; Mardijuwono \& Subianto, 2018; Wiratama \& Budiartha, 2015). However, it is not in line with research that professional skills have no effect on audit quality (Achmad, 2012; Saripudin et al., 2012).

\section{CONCLUSION}

Based on the results and analysis, it concludes that competence has a positive effect on audit quality at the RI Bawaslu. These results can be used as consideration by the RI Bawaslu to further improve the quality of audits on auditors, because the higher the competence of the auditors, the higher the audit quality. However, Independence variable does not have a positive effect on audit quality at the RI Bawaslu. Meanwhile, Professional skills have a positive effect on audit quality at the RI Bawaslu. Profe ssional skills are important things that must be applied by every public accountant in carrying out their professional work in order to achieve adequate audit quality. Based on the conclusions and limitations of the study, it is recommended to expand the object of research, so that the research can be more generalized. Also, it is recommended in the future, to add a structured interview method to each respondent to collect data, so that the possibility of respondents who are not objective in filling out the questionnaire can be avoided.

\section{REFERENCES}

Achmad, B. (2012). Analysis Faktor-Faktor Yang Mempengaruhi Kualitas Hasil Pemeriksaan Audit Sektor Publik (Studi Empiris Pada Bpkp Perwakilan Jawa Tengah). Dinamika Akuntansi Keuangan Dan Perbankan, 1(2). https://unisbank.ac.id/ojs/index.php/fe9/article/view/1591.

Adebayo, 0. (2021). An Empirical Analysis of the Impact of Auditors Independence on the Credibility of Financial Statement in Nigeria. Research Journal of Finance and Accounting, 2(3), 82-99. http://citeseerx.ist.psu.edu/viewdoc/download?doi=10.1.1.859.6071\&rep=rep1\&type=pdf.

Akib, M., \& La. (2021). Effects of Professional Skills and Auditor Competence on Audit Quality in Inspectorate Southeast Sulawesi Province. International Journal of Economics and Business Administration, 9(1), 79-85. https://doi.org/10.35808/ijeba/659.

Alim, M. N., Hapsari, T., \& Purwanti, L. (2007). The effect of competence and independence on audit quality with auditor ethics as moderation variables. National Symposium on Accounting X, 26-28.

Angel RG, G., \& Parlindungan, R. (2016). Pengaruh Independensi Terhadap Kualitas Audit pada Kantor Akuntan Publik Di Palembang dengan Prinsip Kehati-Hatian Sebagai Variabel Moderasi. STIE MDP.

Ardini, L. (2010). Pengaruh kompetensi, independensi, akuntabilitas dan motivasi terhadap kualitas audit. Jurnal Ekonomi Dan Bisnis Airlangga (JEBA), 20(3). https://www.ejournal.unair.ac.id/JEBA/article/download/4264/2904.

Arens, A. A., Elder, R. J., \& Beasley, M. S. (2008). Auditing dan jasa assurance pendekatan terintegrasi. Erlangga.

Arowoshegbe, A., Emmanuel, U., \& Gina, A. (2017). Accounting Ethics and Audit Quality in Nigeria. Asian Journal of Economics, Business and Accounting, 4, 15. 
https://doi.org/10.9734/AJEBA/2017/34826.

Bawono, I. R., \& Singgih, E. (2010). Faktor-Faktor dalam Diri Auditor dan Kualitas Audit: Studi Pada Kap 'Big Four' di Indonesia. Jurnal Akuntansi Dan Auditing Indonesia, 14.

Christiawan, Y. J. (2002). Kompetensi dan independensi akuntan publik: refleksi hasil penelitian empiris. $\begin{array}{lllll}\text { Jurnal Akuntansi Kan } & \text { 79-92. }\end{array}$ http://jurnalakuntansi.petra.ac.id/index.php/aku/article/view/15692.

DeAngelo, L. E. (1981). Auditor size and audit quality. Journal of Accounting and Economics, 3(3), 183-199. https://doi.org/10.1016/0165-4101(81)90002-1.

Deis Jr, D. R., \& Giroux, G. A. (1992). Determinants of audit quality in the public sector. Accounting Review, 462-479. https://www.jstor.org/stable/247972.

Efendy, M. (2010). Pengaruh kompetensi, independensi, dan motivasi terhadap kualitas audit aparat inspektorat dalam pengawasan keuangan daerah (Studi empiris pada Pemerintah Kota Gorontalo). Universitas Diponegoro.

Febriyanti, R. (2014). Pengaruh Independensi, Due Professional Care Dan Akuntabilitas Terhadap Kualitas Audit (Studi Empiris Pada Kantor AkuntanPublik di Kota Padang danPekanbaru). Jurnal Akuntansi, 2(2). http://ejournal.unp.ac.id/students/index.php/akt/article/view/1043

Haeridistia, N., \& Agustin. (2019). The effect of independence, professional ethics \& auditor experience on audit quality. International Journal of Scientific and Technology Research, 8, 24-27. https://farapaper.com/wp-content/uploads/2019/12/Fardapaper-The-Effect-Of-IndependenceProfessional-Ethics-Auditor-Experience-On-Audit-Quality.pdf.

Harris, D., \& Duellman, S. (2021). Auditor competition and auditor independence: The quality of financial statements. Syracuse University.

Iryani, L. (2017). The Effect of Competence, Independence, and Professional Auditors to Audit Quality. JHSS (JOURNAL OF HUMANITIES AND SOCIAL STUDIES), 1, 1-4. https://doi.org/10.33751/jhss.v1i1.363.

Kartika, D., \& Pramuka, B. (2019). The Influence of Competency, Independency, and Professionalism on Audit Quality. Journal of Accounting and Strategic Finance, 2, 157-169. https://doi.org/10.33005/jasf.v2i2.58.

Kumalasari, Y., Dimyati, M., \& Rachmawati, R. (2020). The Effect Of Competency, Independence, Ethics Auditor And Professionalism To The Audit Quality And Emotional Intelligence As A Variable Of Moderation. ABM : International Journal of Administration, Business and Management, 1, 36-50. https://doi.org/10.31967/abm.v1i1.383.

Kusumawati, A., \& Syamsuddin, S. (2018). The effect of auditor quality to professional skepticsm and its relationship to audit quality. International Journal of Law and Management, 60(4), 998-1008. https://doi.org/10.1108/IJLMA-03-2017-0062.

Lamba, R. A., Seralurin, Y. C., Lamba, A., \& Pattiasina, V. (2020). The Effect of Auditor Independence and Ethics on Auditor Professional Scepticism: Its Implications for Audit Quality in Indonesia. International Journal of Innovation, Creativity and Change, 12(8), 383-396. https://www.ijicc.net/images/vol12/iss8/12838_Lamba_2020_E_R.pdf.

Layli, M. (2018). Pengaruh Kompetensi, Independensi, dan Kemahiran Profesional Terhadap Kualitas Audit Pada BPK Perwakilan Provinsi Jawa Tengah. Universitas Islam Indonesia.

Lowenshon, S., Johnson, E. L., \& Elder, J. R. (2005). Auditor Specialization and Perceived Audit Quality. Auditee Satisfaction, and Audit Fees in the Local Government Audit Market.

Manayseh, M., \& Stalin, D. (2020). Auditor Independence and its Impact on Financial Statements Audit (Evidence from Oman). Shanlax International Journal of Commerce, 8, 1-10. https://doi.org/10.34293/commerce.v8i3.2397.

Mardijuwono, A. W., \& Subianto, C. (2018). Independence, professionalism, professional skepticism. Asian Journal of Accounting Research, 3(1), 61-71. https://doi.org/10.1108/AJAR-06-2018-0009.

Marwa, T., Wahyudi, T., \& Kertarajasa, A. (2019). The Effect of Competence, The Effect of Competence, Experience, Independence, Due Professional Care, And Auditor Integrity On Audit Qualitiy With Auditor Ethics As Moderating Variable. Journal of Accounting Finance and Auditing Studies (JAFAS), 5, 80-99. https://doi.org/10.32602/jafas.2019.4.

Mautz, R., \& Sharaf, H. (1961). The Philosophy of Auditing. American Accounting Association.

Meidawati, N., \& Assidiqi, A. (2019). The influences of audit fees, competence, independence, auditor ethics, and time budget pressure on audit quality. Jurnal Akuntansi \& Auditing Indonesia, 23, 117-128. https://doi.org/10.20885/jaai.vol23.iss2.art6.

Mispiyanti, M., \& Wicaksono, R. (2021). Influence Of Competence, Independence, Spiritual Quotient, Emotional Quotient, And Audit Tenure On Audit Quality. Jurnal Akuntansi, 11, 137-148. https://doi.org/10.33369/j.akuntansi.11.2.137-148.

Mulyadi, K. (2002). Auditing. Salemba Empat. 
Muslim, Hajering, \& Muhammad Suun. (2020). Moderating Ethics Auditors Influence of Competence, Accountability on Audit Quality. Jurnal Akuntansi, 23(3), 468. https://doi.org/10.24912/ja.v23i3.614.

Nirmala, R. P. A., \& Cahyonowati, N. (2013). Pengaruh independensi, pengalaman, due professional care, akuntabilitas, kompleksitas audit, dan time budget pressure terhadap kualitas audit (Studi Empiris pada Auditor KAP di Jawa Tengah dan DIY). Fakultas Ekonomika dan Bisnis.

Nurhasanah, N. (2020). Audit Internal, Karakteristik Instansi dan Kasus Korupsi (Studi Empiris di Kementerian/Lembaga). Jurnal Tata Kelola Dan Akuntabilitas Keuangan Negara, 2(1), 27-48. https://www.neliti.com/publications/318564/efektivitas-pengendalian-internal-audit-internalkarakteristik-instansi-dan-kasu.

Perdany, A. (2014). Pengaruh Kompetensi Dan Independensi Auditor Terhadap Kualitas Audit Investigatif Pada Kantor Perwakilan Bpk-Ri Di Yogyakarta. UNS (Sebelas Maret University).

Pritama, Y., Supriana, T., \& Torong, Z. (2018). The Factors of The Infuence on Audit Quality at The Inspectorate General of Ministry of Environment and Foresty. https://doi.org/10.2991/ebic-17.2018.38.

Puspitasari, W., Mafela, A., \& Melani, F. (2019). The Influence Of Independence, Work Experience, Due Professional Care, Accountability, Integrity, And Clients Pressure On Audit Quality. Indonesian Management and Accounting Research, 16, 17. https://doi.org/10.25105/imar.v16i2.4677.

Samelson, D., Lowensohn, S., \& Johnson, L. E. (2006). The determinants of perceived audit quality and auditee satisfaction in local government. Journal of Public Budgeting, Accounting \& Financial Management. https://doi.org/10.1108/JPBAFM-18-02-2006-B001.

Sari, N., \& Susanto, A. (2018). The effect of auditor competency and work experience on information systems Audit quality and supply chain (case study: Indonesian Bank). International Journal of Supply Chain Management, 7, 747-750. https://www.academia.edu/download/58651481/ijscm_publish.pdf.

Saripudin, Herawaty, N., \& Rahayu. (2012). Pengaruh independensi, pengalaman, due professional care dan akuntabilitas terhadap kualitas audit (survei terhadap auditor KAP di jambi dan palembang). EJurnal Binar Akuntansi, 1(1), 4-13.

Sekaran, U. (2011). Research Methods for business Edisi I and 2. Salemba Empat.

Sirois, L.-P., \& Simunic, D. (2011). Auditor Size and Audit Quality Revisited: The Importance of Audit Technology. SSRN Electronic Journal. https://doi.org/10.2139/ssrn.1694613.

Syukroni, H. J. (2018). Faktor-Faktor Yang Mempengaruhi Kualitas Audit Dengan Etika Auditor Sebagai Moderating Variabel. Jurnal Riset Akuntansi Dan Bisnis, 15(1). http://journal.umsu.ac.id/index.php/akuntan/article/view/422.

Tjun, L. T., Marpaung, E. I., \& Setiawan, S. (2012). Pengaruh kompetensi dan independensi auditor terhadap $\begin{array}{llll}\text { kualitas audit. Jurnal 33-56. } & \end{array}$ https://journal.maranatha.edu/index.php/jam/article/view/353.

Widiastuty, E., \& Febrianto, R. (2010). Pengukuran kualitas audit: sebuah esai. Jurnal Ilmiah Akuntansi Dan Bisnis, 5(2), 1-43. https://ojs.unud.ac.id/index.php/jiab/article/download/2621/1833.

Wiratama, W. J., \& Budiartha, K. (2015). Pengaruh Independensi, Pengalaman Kerja, Due Professional Care dan Akuntabilitas Terhadap Kualitas Audit. E-Jurnal Akuntansi Universitas Udayana, 10(1), 91-106. https://ojs.unud.ac.id/index.php/Akuntansi/article/download/9900/8121.

Yazid, H., \& Wiyantoro, L. (2018). The Effect of Work Experience, Internal Auditor Competence, Independence to Due Professional Care and Implications in Internal Audit Quality. Advanced Science Letters, 24, 2565-2568. https://doi.org/10.1166/asl.2018.11006.

Zahmatkesh, S., \& Rezazadeh, J. (2017). The effect of auditor features on audit quality. Tékhne, 15. https://doi.org/10.1016/j.tekhne.2017.09.003.

Zimmerman, J. L. (1977). The municipal accounting maze: An analysis of political incentives. Journal of Accounting Research, 107-144. https://www.jstor.org/stable/2490636. 